\title{
Comparative evaluation of multiple protein extraction procedures from three species of the genus Caulerpa
}

\author{
Sarah Caronni ${ }^{1}$ - Filippa Addis ${ }^{2}$ - Maria Anna Delaria ${ }^{3} \cdot$ Rodolfo Gentili $^{1} \cdot$ Chiara Montagnani $^{1} \cdot$ Augusto Navone $^{4}$. \\ Pieraugusto Panzalis ${ }^{4} \cdot$ Sandra Citterio ${ }^{1}$
}

Received: 21 December 2020 / Revised and accepted: 21 April 2021 / Published online: 10 May 2021

(C) The Author(s) 2021

\begin{abstract}
The aim of this study was to define the simplest and least expensive protocol for total protein extraction for three different macroalgae of the genus Caulerpa (the invasive C. taxifolia and C. cylindracea and the autochthonous C. prolifera). Five multistep protein extraction procedures, set up for other macroalgal species, were tested. For each of them, different pre-treatment and extraction conditions were simultaneously examined, according to a factorial design, considering the starting material, the solvent-to-biomass ratio, and the incubation temperature. Protein yield in the obtained extracts was estimated with the Bradford method. Further, polyacrylamide gel electrophoresis (SDS-PAGE) was used to resolve proteins, assessing their quality and integrity. Significant differences in protein yield were observed among the extraction protocols and the conditions tested, also in relation to the considered species. Profiles having an acceptable quality were obtained for C. prolifera and C. cylindracea, and from the obtained results, the best method to obtain high yield and quality protein extracts for the two above-mentioned species appears to require the use of a primary TCA/acetone extraction buffer followed by a lysis buffer with $\mathrm{NaCl}, \mathrm{KCl}$, urea, Triton, SDS and a protease inhibitor. The best results, in particular, were obtained starting from fresh pulped material with a buffer-tobiomass ratio of 10:1 and an incubation temperature of $4^{\circ} \mathrm{C}$. For C. taxifolia, instead, none of the tested protocols produced satisfactory results and further studies will be required.
\end{abstract}

Keywords Protein extraction protocols $\cdot$ Seaweeds $\cdot$ Caulerpa $\cdot$ SDS-Page $\cdot$ Protein profiles

\section{Introduction}

The genus Caulerpa (Chlorophyta: Bryopsidales) is a group of marine green siphonous algae distributed in tropical and subtropical regions (Ratana-arporn and Chirapart 2006). It includes more than 100 species (Zubia et al. 2020) and is considered as one of the most widespread, conspicuous and abundant groups of seaweeds worldwide (Silva 2003).

Rodolfo Gentili

rodolfo.gentili@unimib.it

1 Department of Earth and Environmental Sciences, University of Milan-Bicocca, Piazza della Scienza 1, I-20126 Milan, Italy

2 Department of Veterinary Medicine, University of Milan, Via dell'Università 6, I-26900 Lodi, Italy

3 Department of Science for Nature and Environmental Resources, Via Piandanna 4, I-07100 Sassari, Italy

4 Marine Protected Area Tavolara Punta Coda Cavallo, Via Dante 1, I-07026 Olbia, Italy
Species belonging to this genus are multinucleate (coenocytic) and colonial and have a modular organization. They are all characterized by the lack of cellulose in the cell walls and present a large phenotypic plasticity and morphological variability resulting in a number of morphological forms and variants (Belleza and Liao 2007). In addition to Caulerpa prolifera (Forsskål) Lamouroux and Caulerpa ollivieri Dostál, which are both native of the Mediterranean Sea (Vaquer-Sunyer et al. 2012; Ortegón-Aznar et al. 2015), six Caulerpa species have been observed in the Mediterranean Sea since the nineteenth century: Caulerpa mexicana Sonder ex Kützing, Caulerpa scalpelliformis (Brown ex Turner) C. Agardh, Caulerpa cylindracea Sonder, Caulerpa taxifolia (Vahl) C. Agardh, and Caulerpa sertularioides (Gmelin) Howe (Olsen et al. 1998). Most of these species have entered the Mediterranean since the opening of the Suez Canal in 1869 and they are restricted to the warm waters of the east and southeastern Mediterranean (Ukabi et al. 2012). Nevertheless, in the last few decades, two of these species, C. cylindracea and C. taxifolia, have significantly expanded their range of distribution in the basin and now are considered 
highly invasive taxa (Jongma et al. 2013; Montefalcone et al. 2015; Piazzi et al. 2016).

Recent studies have demonstrated the direct and indirect key role of specific protein factors in determining the invasive ability of algae, by regulating their adaptation to different environmental conditions (e.g., Contreras et al. 2008; $\mathrm{Xu}$ and Esko 2014; $\mathrm{Xu}$ et al. 2016). Vadlapudi and Kaladhar (2012) highlighted the high potential of protein profile analysis in the study of algae for the understanding of many of the biological/physiological processes that regulate their spread, especially in the case of invasive species. The proteome of a species can be defined as the interface between its genotypic and phenotypic variability. Therefore, it represents the ideal technological approach for studying eco-physiological responses and adaptability, which usually make an alien species a successful invader (Slattery et al. 2012). Nevertheless, proteome analysis has been scarcely applied to bio-ecological studies of the marine environment (Knigge 2015) and especially to macroalgae study (Contreras-Porcia and López-Cristoffanini 2012). Indeed, protein extraction from macroalgae appears to be difficult due to the large amounts of interfering compounds such as phenols, carbohydrates, terpenes, and pigments (Wang et al. 2008a, 2008b; Wu et al. 2014; Mohd Rosni et al. 2015; Cotas et al. 2020) as well as to the significant presence of cell wall anionic polysaccharides (Kraan 2012). After cell disruption, these compounds remain in the extraction medium as hydro-colloidal compounds, increasing extract viscosity and limiting the quantification of soluble macromolecules, including proteins (Joubert and Fleurence 2008). Moreover, protein extraction from seaweed is always a challenging task due to the low protein concentration with the consequent higher chance of coextracting inorganic contaminants such as salts, which may massively deteriorate the resolving power of SDSPAGE and interfere with the current proteomic tools (Lim and Teo 2015). For these reasons, the proteome analysis of macroalgae is even more challenging if compared to other organisms.

The aim of this study was to define the simplest and least expensive protocol for total protein extraction, using low-cost equipment and consumables, for three different macroalgae of the genus Caulerpa and to lay the groundwork for subsequent studies on the protein factors involved in their invasiveness. The three most abundant Caulerpa species in the Mediterranean Sea, the invasive C. taxifolia and C. cylindracea and the autochthonous $C$. prolifera, were considered. Five multi-step protein extraction procedures, set up for other macroalgal species, were tested. For each of them, different pre-treatment and extraction conditions were simultaneously examined, according to a factorial design, considering the starting material, the solvent-to-biomass ratio, and the incubation temperature.

\section{Materials and methods}

\section{Experimental design}

Five different protein extraction protocols were tested. Beside the protocol, the experimental design consisted of 4 other factors: in particular, the species (Caulerpa prolifera vs Caulerpa taxifolia vs Caulerpa cylindracea) and the starting material were considered in the pre-treatment phase as well as the solvent-to-biomass ratio and the incubation temperature during the extraction procedure (Park and Bean 2003; Wang et al. 2006; Guan et al. 2012). Three replicates for each combination of factors were taken into account in an orthogonal design (three different extracts for each combination) $(N=540)$ (Sup. 1).

\section{Sample preparation and extraction procedures}

Caulerpa prolifera, C. cylindracea, and C. taxifolia samples were collected along the coasts of NE Sardinia, in the Marine Protected Area of Tavolara Punta Coda Cavallo during the late spring 2019 and immediately transported to the laboratory, maintaining them in seawater. Separate collections were made for each experimental replicate $(n=3$ collections over 2 weeks) as it was not logistically possible to perform all extractions simultaneously.

The seaweeds were carefully chosen, removing those suspected of having parasites, and blades for the assays were separated. Epiphytes, sand, and silt were removed by washing twice with $3.2 \mathrm{~g}$ per $100 \mathrm{~mL} \mathrm{NaCl}$ (Harnedy and FitzGerald 2013) and twice with sterile seawater using a soft brush, followed by a final rinse in distilled water (Wong et al. 2006). Raw biomass was then pre-treated according to three different procedures: (1) oven-dried $\left(55^{\circ} \mathrm{C}\right.$ for $\left.48 \mathrm{~h}\right)$ and milled $(<1 \mathrm{~mm})(\mathrm{DM})$; (2) ground to a fine powder in liquid nitrogen using a mortar and pestle (LN); (3) fresh, pulped, filtered (through Whatman filter paper 1; Safdar et al. 2017), and ground using a mortar and pestle (FP) (Wong et al. 2006; Angell et al. 2017). The seaweed pretreated materials obtained were then processed following 5 different protein extraction protocols (PEPs) (Fig. 1). During each protocol, each of the three pre-treated materials was alternatively incubated at two different temperatures $\left(4^{\circ} \mathrm{C}\right.$ and $30^{\circ} \mathrm{C}$ ) (Barbarino and Lourenço 2005; Angell et al. 2017) with two different volumes (1:10 or 1:5) of the specific extraction buffer (Rice and Crowden 1987; Angell et al. 2017) (Fig. 1).

Protocol $1\left(\right.$ PEP $\left._{1}\right)-$ modified from Harnedy and FitzGerald (2013)

This protocol included two subsequent extraction steps. Initially, $0.5 \mathrm{~g}$ of seaweed starting material (LN, FP, DM) 


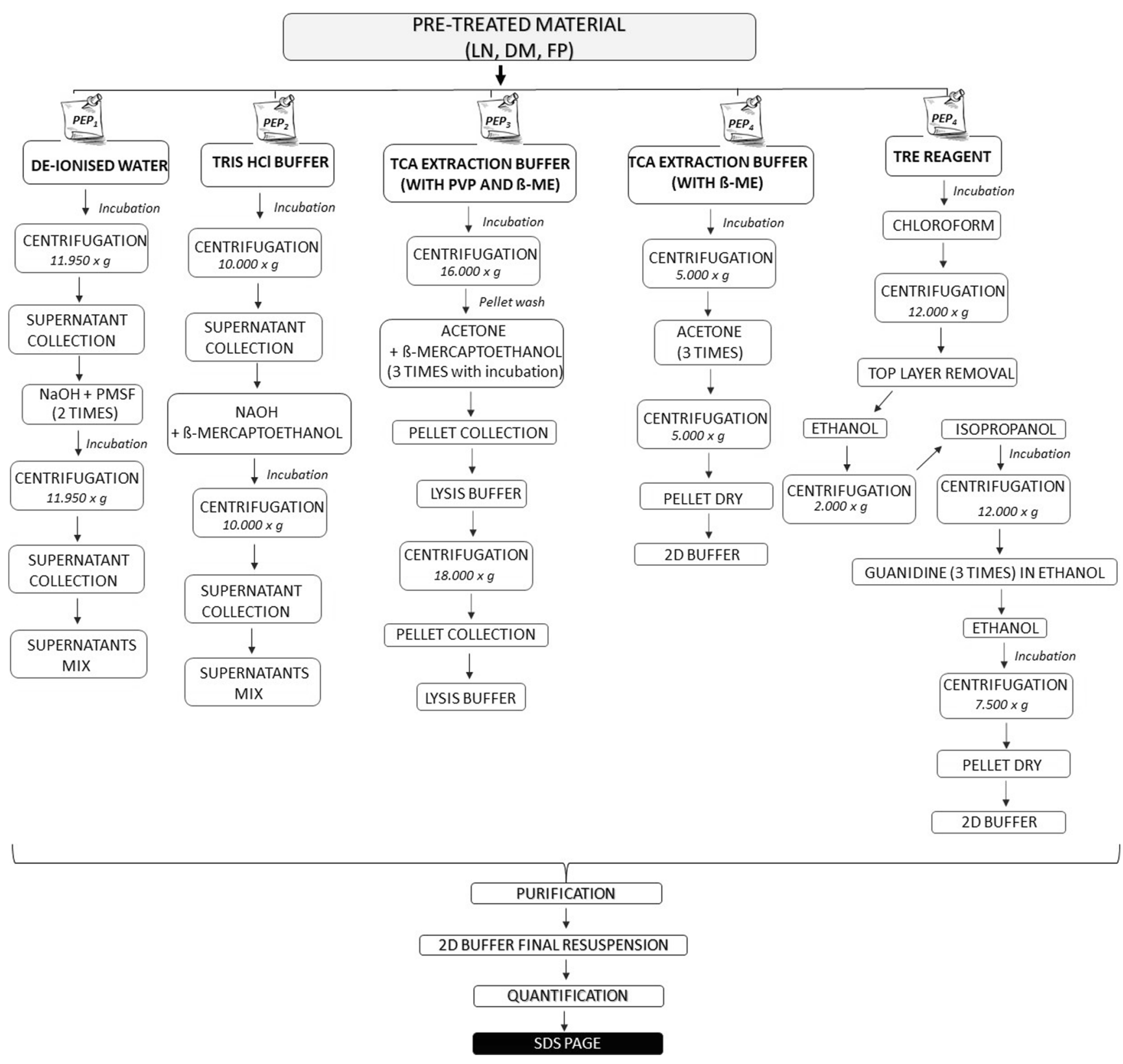

Fig. 1 Flowchart of the tested protein extraction methods

was suspended in the two considered volumes (1:10 and 1:5 $\mathrm{w} / \mathrm{v})$ of de-ionized water and stirred gently on a rotating drum for $16 \mathrm{~h}$ at $4^{\circ} \mathrm{C}$ or $30^{\circ} \mathrm{C}$, alternatively. The proteins in the aqueous extracts were collected by centrifugation at $11,950 \times \mathrm{g}$ for $20 \mathrm{~min}$ at $4^{\circ} \mathrm{C}$. For alkaline-soluble protein extraction, the pellet was resuspended in $\mathrm{NaOH}\left(0.12 \mathrm{~mol} \mathrm{~L}^{-1}\right)$ containing $0.5 \mathrm{~g}$ per $100 \mathrm{~mL}$ of phenylmethanesulfonyl fluoride (PMFS) at a weight:volume of $1: 15$, stirred for $1.5 \mathrm{~h}$ at $30^{\circ} \mathrm{C}$, and then centrifuged at $11,950 \times \mathrm{g}$ for $20 \mathrm{~min}$ at room temperature. Alkaline extractions were performed twice on each test sample and the two supernatants were combined. Finally, the water-soluble and alkaline-soluble protein fractions were combined (Fig. 1).
Protocol $2\left(\mathrm{PEP}_{2}\right)$ - modified from Fleurence et al. (1995)

Initially, $10 \mathrm{~g}$ of seaweed material obtained according to three tested pre-treatment procedures (LN, FP, DM) was suspended into the two tested volumes $(1: 10$ and $1: 5 \mathrm{w} / \mathrm{v})$ of a specific Tris HCI buffer $(0.1 \mathrm{M} \mathrm{pH} 7.5)$ and stirred on a rotating drum for $16 \mathrm{~h}$ at the two considered temperatures $\left(4\right.$ and $\left.30^{\circ} \mathrm{C}\right)$. The sample was then centrifuged at $10,000 \times \mathrm{g}$ for $20 \mathrm{~min}$ at room temperature. The supernatant and the pellet were recovered, and the pellet was treated with $\mathrm{NaOH}(0.1 \mathrm{M})$ in presence of $\beta$-mercaptoethanol $(0.5 \% \mathrm{v} / \mathrm{v})$. The obtained mixture was gently stirred at room temperature for $1 \mathrm{~h}$ and then centrifuged at $10,000 \times \mathrm{g}$ for $20 \mathrm{~min}$ at room temperature. The supernatant 
was collected and combined with the supernatant of the first centrifugation (Fig. 1).

\section{Protocol $3\left(\mathrm{PEP}_{3}\right)$ - modified by Gao et al. (2016)}

Tissues $(100 \mathrm{mg})$ were pre-treated according to the three above-described procedures (LN, DM, FP) and resuspended in a 1:10 and 1:5 volume of prechilled extraction buffer (10\% TCA, $1 \%$ polyvinylpyrrolidone, and $2 \% \beta-$ mercaptoethanol in acetone). Samples were then stirred gently on a rotating drum for $30 \mathrm{~min}$ at 4 and $30^{\circ} \mathrm{C}$ alternatively. The obtained solutions were then centrifuged at $16,000 \times g$ for $15 \mathrm{~min}$ at $4^{\circ} \mathrm{C}$, the supernatant was discarded, and the pellet was rinsed three times with $1 \mathrm{~mL}$ prechilled acetone with $0.07 \% \beta$-mercaptoethanol. Between each rinse, the mixture was incubated at $-20^{\circ} \mathrm{C}$ for $1 \mathrm{~h}$. The pellet was resuspended in an appropriate volume of lysis buffer (1 $\mathrm{mL}$ for $100 \mathrm{mg}$ of initial material) composed by $150 \mathrm{mM}$ $\mathrm{NaCl}, 100 \mathrm{mM} \mathrm{KCl}, 8 \mathrm{M}$ urea, 2\% (v/v) Triton, 01\% (v/v) SDS, and 1 tablet protease inhibitor (Roche). A decrease in the stability of proteins was described for tetraethylammonium bromide (TEAB) by Banerjee and Kishore (2008). Therefore, $\mathrm{NaCl}$ and $\mathrm{KCl}$ were used instead of TEAB for their capacity to adjust ionic strength stabilizing protein structure (Hellerbrand et al. 2001). Samples were then incubated at room temperature for $60 \mathrm{~min}$. Finally, a centrifugation at $18,000 \times g$ for $1 \mathrm{~h}$ at room temperature was performed and a new aliquot of lysis buffer was added to the obtained pellet (Fig. 1).

\section{Protocol $4\left(\mathrm{PEP}_{4}\right)$ - Isaacson et al. (2006)}

The seaweed material $(100 \mathrm{mg})$ obtained according to three tested pre-treatment procedures (LN, FP, DM) was alternatively suspended in $1 \mathrm{~mL}(1: 10 \mathrm{w} / \mathrm{v})$ or $0.5 \mathrm{~mL}(1: 5 \mathrm{w} / \mathrm{v})$ of TCA extraction buffer (TCA/acetone ice cold to $10 \%$ (vol/ vol)) with $\beta$-mercaptoethanol to a final concentration of $2 \%$ $(\mathrm{v} / \mathrm{v})$ added immediately before use, and incubated on a rotating drum for $16 \mathrm{~h}$ at the two considered temperatures (4 and $30^{\circ} \mathrm{C}$ ). Samples were then centrifuged for $30 \mathrm{~min}$ at $5000 \times g$ at $4^{\circ} \mathrm{C}$ and the supernatant was carefully pipetted out and discarded. Then, $10 \mathrm{~mL}$ ice-cold acetone was added to the pellet and samples were centrifuged for $10 \mathrm{~min}$ at $5000 \times \mathrm{g}$ at $4^{\circ} \mathrm{C}$. The supernatant was carefully removed with the pipette and discarded. The acetone step was repeated three times and the pellet was finally dried gently in a fume hood in ice (to prevent protein oxidation), transferred to a $1.5-\mathrm{mL}$ microcentrifuge tube, and resuspended in an appropriate volume (125 $\mu \mathrm{L}$ for each $\mathrm{mL}$ of initial TCA solution) of a buffer for protein resuspension ( $2 \mathrm{D}$ buffer: urea $7 \mathrm{M}$; thiourea $2 \mathrm{M}$; CHAPS 2\%) (Fig. 1).
Protocol 5 (PEP5) — modified by Wong et al. (2006)

The seaweed tissue $(100 \mathrm{mg})$ was treated in accordance with the three above-described pre-treatment procedures (LN, FP, $\mathrm{DM})$ with 1 or $0.5 \mathrm{~mL}$ of Tri Reagent ${ }^{\circledR}$ (Sigma), in order to obtain the two considered solvent-to-biomass ratios (1:10 and $1: 5 \mathrm{w} / \mathrm{v}$ ) and mantained at room temperature for $5 \mathrm{~min}$. Subsequently, $200 \mu \mathrm{L}$ of chloroform was added to the cell lysate and the mixture was allowed to stand for $5 \mathrm{~min}$ at room temperature before being centrifuged at $12.000 \times \mathrm{g}$ for $10 \mathrm{~min}$, alternatively, at 4 or $30^{\circ} \mathrm{C}$. The top pale-yellow layer was then removed, $300 \mu \mathrm{L}$ of ethanol was added to resuspend the reddish bottom layer, and the obtained mixture was centrifuged at $2000 \times \mathrm{g}$ for $5 \mathrm{~min}$ at $4{ }^{\circ} \mathrm{C}$. The supernatant was transferred to a new tube and $1.5 \mathrm{~mL}$ of isopropanol was added. The mixture was allowed to stand for at least $10 \mathrm{~min}$ for precipitation of proteins at room temperature and it was then centrifuged at $12.000 \times g$ for $10 \mathrm{~min}$ at $4^{\circ} \mathrm{C}$. The obtained pellet was washed three times with $2 \mathrm{~mL}$ of guanidine hydrochloride $0.3 \mathrm{M}$ in ethanol $95 \%$ for $20 \mathrm{~min}$ at room temperature, centrifuging at $7.500 \times \mathrm{g}$ for $5 \mathrm{~min}$ after each. Finally, the pellet was briefly washed with $100 \%$ ethanol ( $1 \mathrm{~mL}$ for each $\mathrm{mL}$ of Tri Reagent) and maintained at room temperature for $5 \mathrm{~min}$. A further centrifugation at $7.500 \times \mathrm{g}$ for $5 \mathrm{~min}$ at $4^{\circ} \mathrm{C}$ was performed before removing the supernatant. The pellet was then air-dried for $30 \mathrm{~min}$ and resuspended in a buffer appropriate for the downstream analytical approach (2D buffer: urea $7 \mathrm{M}$; thiourea $2 \mathrm{M}$; CHAPS 2\%) (Fig. 1).

\section{Additional purification, protein quantification, and residual phenol estimation}

Salt, metabolite, intracellular components, and pigment contamination were removed using the commercially available clean-up kit from GE Healthcare (India), as suggested by Karthikaichamy et al. (2017), and resuspended in an appropriate volume $(50 \mu \mathrm{L}$ for $400 \mu \mathrm{L}$ of extract) of a buffer for protein resuspension ( 50 buffer) ( $2 \mathrm{D}$ buffer: urea $7 \mathrm{M}$; thiourea 2M; CHAPS 2\%).

The Bradford method was then used for the quantification of the total protein concentration (Bradford 1976). The spectrophotometric absorbance of the unknown sample was determined by measuring absorbance at $595 \mathrm{~nm}$ (NP80 NanoPhotometer, Implen) against a linear calibration curve prepared using standard solutions of bovine serum albumin (BSA). Protein concentrations were expressed as micrograms per microliter.

Finally, the residual amount of phenolic compounds, the main interfering compounds in plant tissues (Wu et al. 2014), was estimated with Folin-Ciocalteau's reagent according to Chandini et al. (2008) in order to evaluate their interference on both the yield and the quality (SDS-PAGE) of extracts. 


\section{SDS-PAGE and gel staining}

To assess protein quality and integrity, $10 \mu \mathrm{g}$ of proteins (only from the sufficiently concentrated extracts) was resuspended in loading buffer (1:4 v/v of Laemmli Sample Buffer, Laemmli 1970), boiled, and loaded in the wells of a $14 \%$ polyacrylamide gel and subjected to sodium dodecyl sulfate polyacrylamide gel electrophoresis (SDS-PAGE). The proteins were revealed by Coomassie Blue staining (Ghiani et al. 2016).

\section{Statistical analysis}

The software GMAV5 (University of Sydney, Australia) was used for statistical analysis. The ANOVA test was applied when normality and homogeneity of variance were satisfied. Furthermore, where the ANOVAs provided significant results, the Student-Newman-Keuls (SNK) a posteriori test was performed (Underwood 1997).

The response variable was the concentration of proteins in the samples of the three species according to the different protocols and extraction conditions. The following fixed factors were considered: protocol with 5 levels $\left(\mathrm{P}_{1}\right.$ vs $\mathrm{P}_{2}$ vs $\mathrm{P}_{3}$ vs $\mathrm{P}_{4}$ vs $\mathrm{P}_{5}$ ), species with three levels (C. prolifera vs C. cylindracea vs $C$. taxifolia), starting material (frozen fresh tissue in liquid nitrogen vs fresh and pulped tissue vs ovendried and milled tissue), solvent-to-biomass ratio (10:1 vs $5: 1)$, and incubation temperature $\left(4^{\circ} \mathrm{C}\right.$ vs $\left.30^{\circ} \mathrm{C}\right)$. The Student-Newman-Keuls (SNK) tests were used for a posteriori comparison of means where the ANOVA test provided significant results (Underwood 1997).

Total phenolic content data were also analyzed with a oneway ANOVA considering extract as a fixed factor with 6 levels. The Student-Newman-Keuls (SNK) tests were used for a posteriori comparison of means where the ANOVA test provided significant results (Underwood 1997).

\section{Results}

\section{Protein concentration}

Significant differences in protein extraction yield were observed among the extraction protocols and conditions tested, also in relation to the considered species (Sup. 2). Figure 3 illustrates the mean protein concentration obtained for each of the three species when applying the five protocols and changing the initial material, the solvent-to-biomass ratio, and the incubation temperature. In particular, quite low protein concentrations were observed for protocol 1 , for which the mean values did not exceed $0.15 \mu \mathrm{g} \mu \mathrm{L}^{-1}$ for C. prolifera and C. cylindracea and $0.27 \mu \mathrm{g}^{-1}$ for $C$. taxioflia for which higher values were generally observed (Sup. 2; Fig. 2). The mean protein concentrations were also quite low for protocol 2. Some differences were observed only among species independently from the extraction conditions. In particular, mean concentrations were quite similar for $C$. prolifera and C. cylindracea (max. $0.17 \mu \mathrm{g} \mu \mathrm{L}^{-1}$ ) while relatively higher values were observed for C. taxifolia $\left(0.33 \mu \mathrm{g} \mu \mathrm{L}^{-1}\right)$ (Sup. 2; Fig. 2).

On the other hand, protocols 3 and 4 provided higher protein concentrations, although some significant differences among species and extraction conditions were observed. Concerning the species, protocol 3 generated quite low protein concentrations for $C$. taxifolia (max. $0.25 \mu \mathrm{g} \mu \mathrm{L}^{-1}$ ) with no differences among extraction conditions, while it produced high protein concentrations for both $C$. prolifera and C. cylindracea (Sup. 2; Fig. 2). The highest ones were obtained using liquid nitrogen ground tissues and fresh pulped tissues. In the case of fresh pulped tissues, the highest concentrations for both species were obtained with a solution-to-biomass ratio of 10:1 and an incubation temperature of $4^{\circ} \mathrm{C}(1.35$ and $1.32 \mu \mathrm{g}$ $\mu \mathrm{L}^{-1}$ respectively for $C$. prolifera and C. cylindracea). For C. cylindracea, quite high concentrations were also observed in the same conditions when the ratio was 5:1 $\left(1.30 \mu \mathrm{g} \mu \mathrm{L}^{-1}\right)$ (Sup. 2; Fig. 2), while significantly lower values were observed when incubating at $30^{\circ} \mathrm{C}\left(\max 0.56 \mu \mathrm{g} \mu \mathrm{L}^{-1}\right)$. Concerning liquid nitrogen ground samples, lower concentrations were recorded for all the extraction conditions, with the lowest ones for oven-dried and milled samples (DM: max. $0.29 \mu \mathrm{g} \mu \mathrm{L}^{-1}$ ). While for the former there were no differences among extraction conditions, for the latter, we observed significant differences depending on the solvent-to-biomass ratio and on the incubation temperature. Higher values were obtained with a ratio of $1: 10$, especially when the incubation temperature was $4^{\circ} \mathrm{C}\left(1.06\right.$ and $1.03 \mu \mathrm{g} \mu \mathrm{L}^{-1}$ respectively for $C$. prolifera and C. cylindracea) (Sup. 2; Fig. 2).

Protocol 4 produced high protein concentrations only with C. prolifera, especially when using liquid nitrogen ground tissues, a solvent-to-biomass ratio of 5:1, and an incubation temperature of $4{ }^{\circ} \mathrm{C}\left(1.39 \mu \mathrm{g} \mu \mathrm{L}^{-1}\right)$ (Sup. 2; Fig. 2). The protein concentration was significantly lower, even with the same solvent-to-biomass ratio, when samples were incubated at $30^{\circ} \mathrm{C}\left(0.54 \mu \mathrm{g} \mathrm{L}^{-1}\right)$. Lower protein concentrations were observed in all the other extraction conditions (max. $0.36 \mu \mathrm{g}$ $\mu \mathrm{L}^{-1}$ ). For $C$. cylindracea and especially for C. taxifolia, significantly lower concentrations were obtained with protocol 4 ; no differences among extraction conditions were recorded for both species (max. $0.37 \mu \mathrm{g} \mu \mathrm{L}^{-1}$ ) (Sup. 2; Fig. 2).

Finally, the highest protein concentration for $C$. taxifolia $\left(\sim 1.17 \mu \mathrm{g} \mu \mathrm{L}^{-1}\right)$ was obtained with protocol 5, both using fresh pulped tissues or liquid nitrogen ground tissues, but only with a 10:1 buffer ratio and an incubation temperature of $4{ }^{\circ} \mathrm{C}$ (Sup. 2; Fig. 2). In the other experimental conditions, protein concentration was lower, reaching the lowest values with oven-dried and milled starting material $\left(\max 0.32 \mu \mathrm{g} \mu \mathrm{L}^{-1}\right.$ ) (Sup. 2; Fig. 2). 


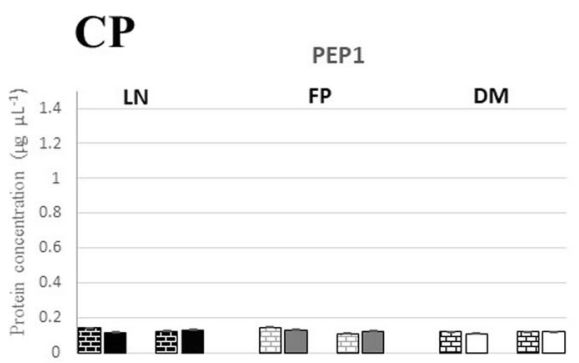

PEP2

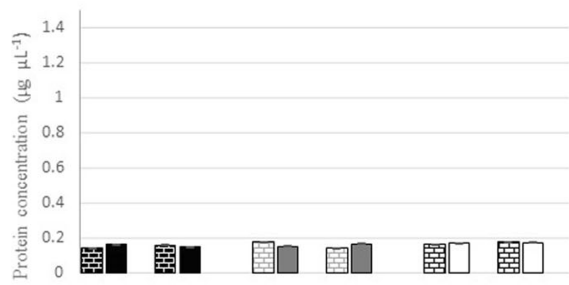

PEP3

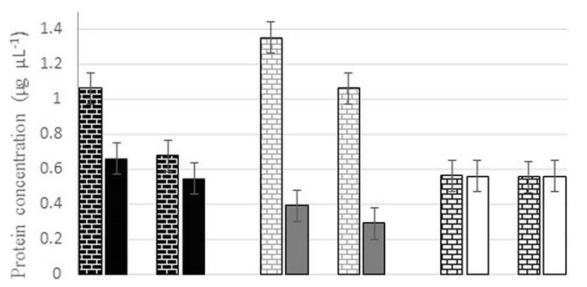

PEP4

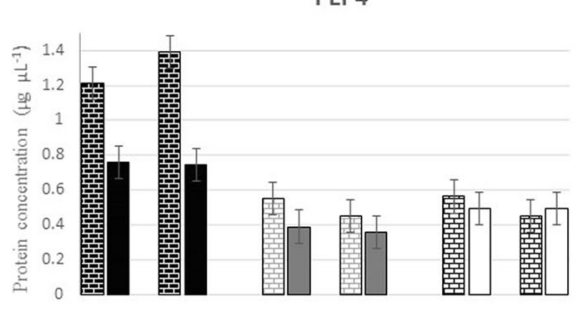

PEP5

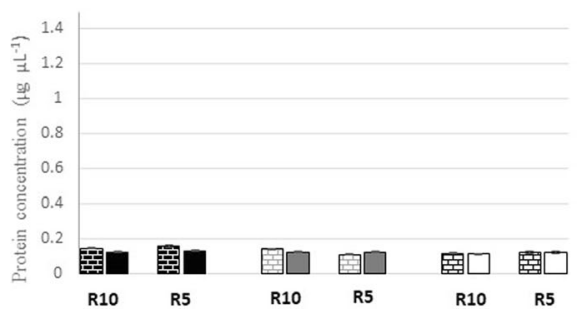

Fig. 2 Mean $( \pm \mathrm{SE})$ protein concentration of the extracts from C. prolifera $(\mathrm{CP})$, C. cylindracea $(\mathrm{CC})$, and C. taxifolia $(\mathrm{CT})$ obtained by different methods. PEP, protocols 1-5; LN, liquid nitrogen; FP, fresh

\section{Protein profiles}

Most of the SDS-PAGE profiles of the tested protein extracts appeared to be qualitatively very low. In Fig. 4, the only profiles having an acceptable quality are presented for the three species. They were all obtained from the extracts with the

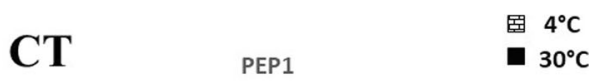

FP DM

LN FP DM

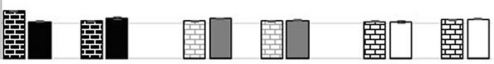

PEP2

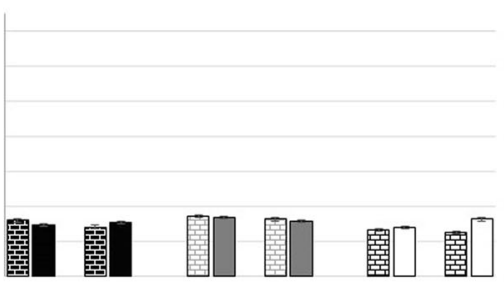

PEP3

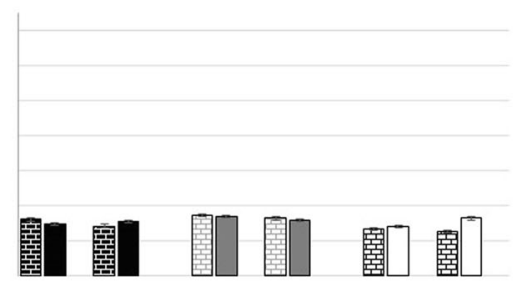

PEP4

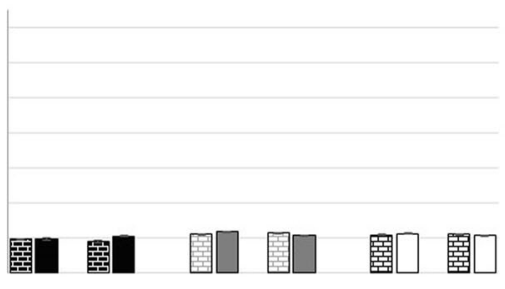

PEP5

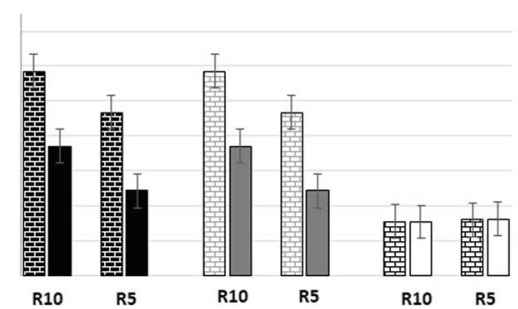

pulped; DM, oven-dry milled; R5 and R10, 5:1 and 10:1 solvent-tobiomass ratio; 4 and $30^{\circ} \mathrm{C}$, incubation temperatures

highest protein yields ( $>1.30 \mu \mathrm{g} \mu \mathrm{L}^{-1}$ for $C$. prolifera and C. cylindracea and $>1.00 \mu \mathrm{g} \mu \mathrm{L}^{-1}$ for C. taxifolia), specifically by:

- Protocols 3 and 4 for $C$. prolifera (fresh pulped material and tissues grinded in liquid nitrogen using a 10:1 and 5:1 

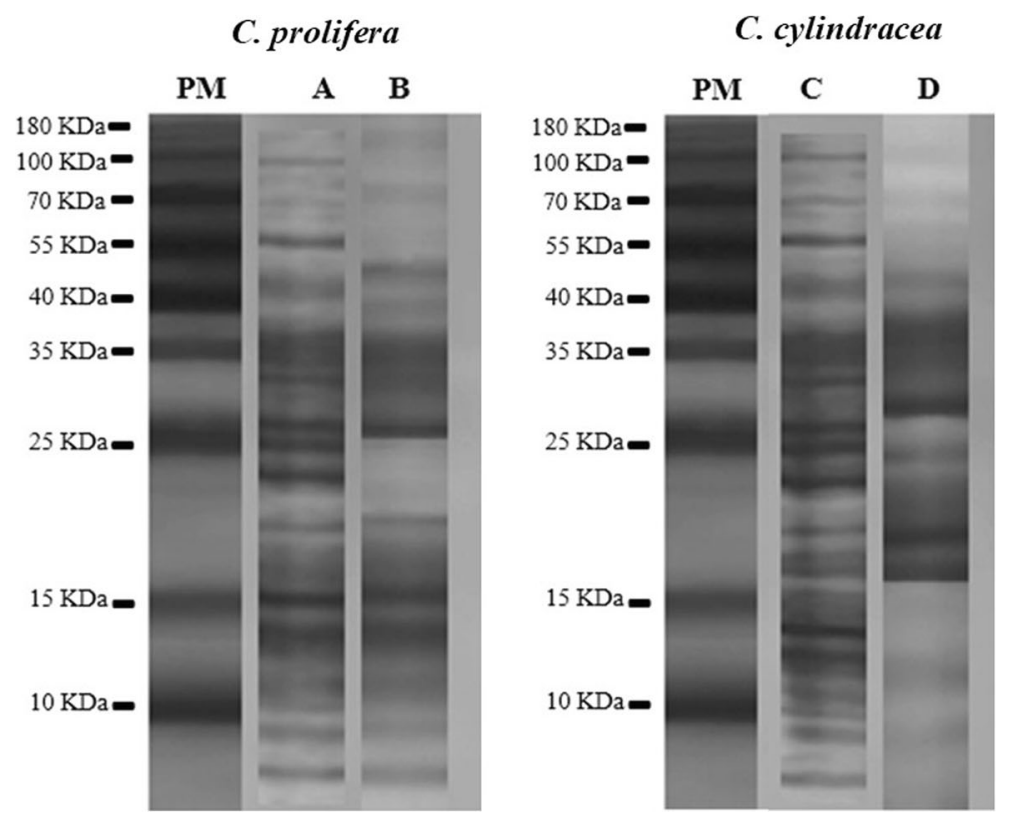

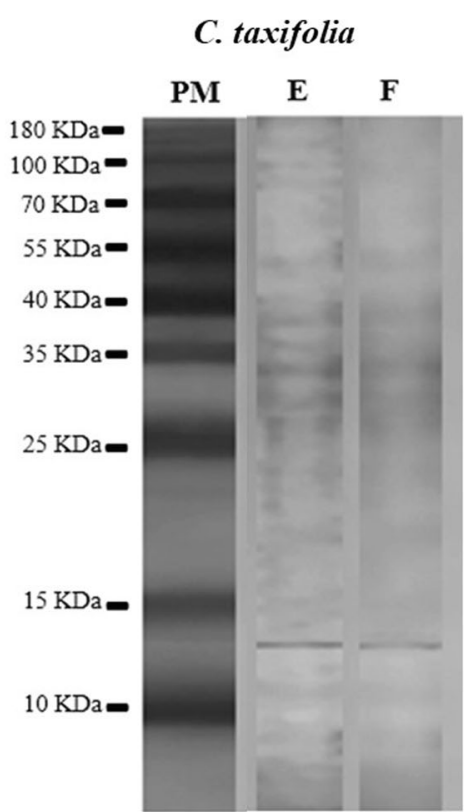

Fig. 3 Highest quality SDS-PAGE gels of proteins for the three species. C. prolifera (A and B), C. cylindracea (C and D), C. taxifolia (E and F). For C. prolifera: lane A: protocol 3 - fresh pulped material with a bufferto-biomass ratio of $10: 1$ incubated at $4^{\circ} \mathrm{C}$; lane $\mathrm{B}$ : protocol $4-$ fresh tissues grinded in liquid nitrogen with a buffer-to-biomass ratio of 5:1 incubated at $4^{\circ} \mathrm{C}$. For C. cylindracea: lane C: protocol 3 - fresh pulped

buffer-to-biomass ratios, incubated at $4^{\circ} \mathrm{C}$ ) (Fig. 3 lanes A and $\mathrm{B}$ ).

- Protocol 3 for C. cylindracea (10:1 and 5:1 buffer-tobiomass ratios, starting from fresh pulped material, incubated at $4^{\circ} \mathrm{C}$ ) (Fig. 3 lanes $\mathrm{C}$ and D).

- Protocol 5 for C. taxifolia extracts (fresh pulped material and liquid nitrogen ground tissues, using a buffer-tobiomass ratio of $10: 1$, incubated at $4^{\circ} \mathrm{C}$ ) (Fig. 3 lanes $\mathrm{E}$ and F).

The profiles revealed significant qualitative differences also among the above-mentioned extracts. Indeed, only two lanes showed patterns containing approximately 20-25 clearly resolved discrete bands with molecular weights from 6.5 to $116 \mathrm{kDa}$ (Fig. 3 lanes A and C). These corresponded to C. prolifera and C. cylindracea extracts obtained with protocol 3 from fresh pulped material, with a buffer-to-biomass ratio of 10:1 and incubated at $4^{\circ} \mathrm{C}$. Comparable band patterns were observed in terms of MW and abundance, although with some slight differences around 1014 and $17-22 \mathrm{kDa}$. The lowest number of bands $(<10)$ was obtained for C. taxifolia (Fig. 3 lanes E and F). The profile was also poorly resolved, especially when the starting material was treated with liquid nitrogen (lane F).

Analyzing the total phenol content in the considered extracts, a correspondence with the quality of SDS-PAGE profiles was highlighted. Indeed, in all the extracts having low yields (for which the profiles were not reported), the residual amount material with buffer-to-biomass ratio of $10: 1$ incubated at $4^{\circ} \mathrm{C}$; lane $\mathrm{D}$ : protocol 3 - fresh pulped material with buffer-to-biomass ratio of 10:1 incubated at $4{ }^{\circ} \mathrm{C}$. For C. taxifolia: lane E: protocol 5 - fresh pulped material with buffer-to-biomass ratio of $10: 1$ incubated at $4^{\circ} \mathrm{C}$; lane $\mathrm{F}$ : protocol 5 - fresh tissues grinded in liquid nitrogen with buffer-tobiomass ratio of $5: 1$ incubated at $4{ }^{\circ} \mathrm{C}$

of phenols was significantly high $\left(>50 \mathrm{mg}^{\mathrm{PGE} \mathrm{g}^{-1} \text { dry }}\right.$ weight). Lower amounts were instead observed in the extracts with the highest yields (for which the profiles are presented in Fig. 3). Anyway, also considering only the extract with highest protein yields, TPC showed a large variability (ANOVA: $F_{2,12}=4198.02 ; P<0.01$ ), ranging from 5.43 to $29.54 \mathrm{mg}$ PGE $\mathrm{g}^{-1}$ dry weight. Overall, the lowest TPC for both $C$. prolifera and $C$. cylindracea $\left(\mathrm{SNK}_{(\mathrm{SE}: 0.1668)}=\mathrm{C}<\mathrm{B}<\mathrm{A}<\mathrm{D}<\mathrm{E}=\mathrm{F}\right)$ was observed with protocol 3 (bar A, CP: 7.48 PGE g ${ }^{-1}$ dry weight and bar C, CC: 5.43 PGE g $^{-1}$ dry weight) using fresh pulped material in 10:1 ratio. The highest TPC for $C$. cylindracea was observed with protocol 3 (bar D, 15.12 PGE $\mathrm{g}^{-1}$ dry weight), once again with fresh pulped material but with a solvent-tobiomass ratio of 5:1. The highest TPC for $C$. prolifera and for C. cylindracea were measured with protocol 4 (bar B, 9.29 PGE ${ }^{-1}$ dry weight; bar D: 14.95 PGE g $^{-1}$ dry weight, respectively) starting from tissues frozen in liquid nitrogen at a 5:1 ratio. Finally, the highest TPC for C. taxifolia (bars E and F, 29.00 PGE g ${ }^{-1}$ dry weight) was observed with protocol 5 , both starting from fresh pulped material or liquid nitrogen ground tissues at a 10:1 ratio.

\section{Discussion}

In recent years, the great effort to optimize the proteome analysis provided standard protein extraction protocols for a wide diversity of organisms (Ünlü et al. 1997; Gygi et al. 2000; 


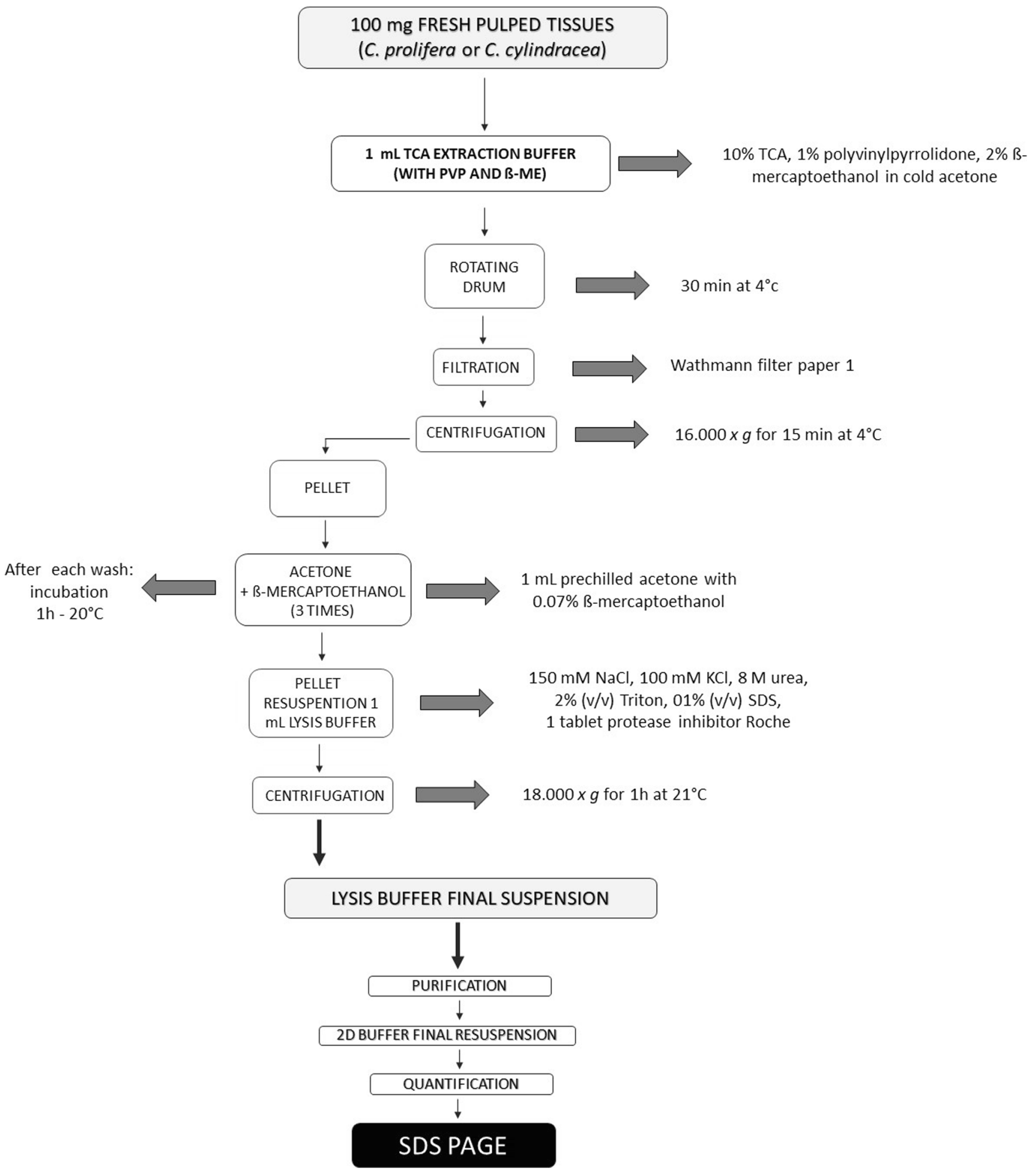

Fig. 4 Final suggested extraction protocol for C. prolifera and C. cylindracea

Jacobs et al. 2001; Beranova-Giorgianni 2003; Yan et al. 2006). However, for most marine algae, available protein extraction methods still appear to be incapable of producing high-quality extracts (Barbarino and Lourenço 2005). This study provides a simple and efficient protein extraction protocol for the three seaweeds of the genus Caulerpa most spread in the Mediterranean Sea: C. prolifera, C. taxifolia, and C. cylindracea.

In our study protein concentration and quality varied greatly depending on the extraction protocol and conditions, and relevant qualitative and quantitative differences were observed for the three species. Moreover, the obtained results 
appeared to be in discordance with those of the only other study available in literature on protein extraction methods for two species of the Caulerpa genus, in which an extraction protocol based on a TRIS HCl buffer was used (Mohd Rosni et al. 2015).

Some of the tested protocols provided quite poor extracts for all the species, with a mean concentration lower than $0.20 \mu \mathrm{g} \mu \mathrm{L}^{-1}$; moreover, none of the applied modifications to these protocols significantly improved the protein yield. The lowest protein concentrations were obtained with protocols 1 and 2, for which an aqueous two-phase system procedure was required, suggesting that this approach is not suitable for the considered species. These results are in accordance with Fleurence et al. (1995) and highlight that, even if alkaline extraction certainly acts by reducing the interactions between polysaccharides and proteins and aids disruption of the cell wall (Zhang et al. 2015), a denaturation effect of basic media on the tertiary structure of proteins anyway occurs. Harnedy and FitzGerald (2013) stated that the quantity of proteins interested by interactions with polysaccharides in naturally coexisting systems can significantly vary depending on the species of macroalgae. For species characterized by low interactions between the two compounds, the negative denaturing and membrane-damaging effect of $\mathrm{NaOH}$ can indeed exceed the positive one provided by the limitation of the interactive effect, as already observed for other organisms by Guo and Lee (2014). Likely this is what happens for the three tested Caulerpa species containing quite high phenol amounts (Matanjun et al. 2008).

The results obtained with the other three protocols were quite different and strictly related both to the species and to the tested extraction conditions. Protocols 3 and 4 produced good concentration and quality extracts for $C$. prolifera and C. cylindracea while a significantly lower protein yield was obtained for C. taxifolia, for which protocol 5 appeared to be more suitable. As both protocols 3 and 4 require the use of a primary TCA/acetone extraction buffer, these results suggest that TCA represents an efficient buffer for protein extraction for at least two of the tested species. TCA precipitates protein by sequestering the protein-bound water and the acidic property of TCA is important for the conformational change that triggers protein precipitation (Rajalingam et al. 2009). Moreover, TCA can inhibit protease activity, which could remarkably improve protein yield (Gao et al. 2015) and usually offers high-quality extracts also in terms of protein profile resolution (García-Otero et al. 2013). In particular, a solution of $10 \%$ TCA in cold acetone, as the one used in protocols 3 and 4 , is considered to be one of the conventional removal of non-protein contaminants that, directly washing contaminants out of tissue powder, produces the highest quality extracts for a lot of different species (Wang et al. 2003).

Anyway, some interesting differences were highlighted in both protein concentration and profiles between the two protocols. While for $C$. prolifera both protocols provided high protein yields, at least in terms of concentration, for C. cylindracea, only protocol 3 appeared to produce rich protein extracts. The main differences appear to be the additives used in the TCA solution and the washing procedure in acetone. Specifically, protocol 3 involves the addition of polyvinylpyrrolidone (PVP) to the TCA solution. PVP is a quite commonly used additive for plant extracts, as it efficiently binds phenols and prevents deactivation of enzymes (Loomis et al. 1979). Thus, the PVP addition may significantly reduce the phenolic interference during extraction (Contreras et al. 2008), partially explaining the success of protocol 3 for Caulerpa species with high polyphenols (Matanjun et al. 2008). The addition of $\beta$ mercaptoethanol to acetone during post-extraction washes may also have contributed to the protocol success. Xu et al. (2008) demonstrated that secondary washes with acetone containing $\beta$-mercaptoethanol facilitate the removal of pigments and lipids improving protein yield. Finally, the higher yields observed for C. prolifera and C. cylindracea with protocol 3 can be explained also considering that a specific lysis buffer was used after extraction instead that a standard 2D buffer, as in protocol 4. According to Wang et al. (2008a, 2008b), total protein resolubilization can be problematic after TCA precipitation, and re-suspending samples in suitable post-extraction buffers can help. Accordingly, Gromov et al. (2008) demonstrated the efficacy of a wide range of buffers in obtaining good yields. Peach et al. (2015) also observed that using an appropriate lysis buffer, especially containing urea or thiourea compounds, can favor protein solubilization. The lysis buffer composition of protocol 3 was modified as recommended by these authors (Peach et al. 2015).

Protocol 3 appeared to be more efficient also in terms of protein quality, since it led to a satisfactory resolution of protein bands by SDS-PAGE. For $C$. prolifera, also an extract obtained with protocol 4 was analyzed by SDS-PAGE due to its high protein concentration $\left(>1.30 \mu \mathrm{g} \mu \mathrm{L}^{-1}\right)$. Nevertheless, in this case, significant smearing and background were observed, suggesting that the protein content may have been overestimated due to the presence of some impurities which were removed by organic solvent washes in protocol 3 (Gao et al. 2015).

For C. taxifolia, protocol 5 (that appeared not suitable for the other two species) provided better results than the other protocols, at least in terms of protein concentration. However, SDS-PAGE profiles were not satisfactory. In this case, in addition to polyphenols and according to Wang et al. (2003), we suppose that the terpene content (very high in May, when the samples of this species were collected) may have been the main cause of interference during protein extraction (C. taxifolia $9.00 \%$ of dry weight vs $0.50 \%$ for C. cylindracea and $0.30 \%$ for C. prolifera; Box et al. 2010).

Finally, in the case of the best performing protocols, some interesting differences in yield were also observed in 
function of the tested extraction conditions. Concerning the starting material, frozen tissue chilled and grinded in liquid nitrogen provided the best results with protocol 4 , whereas by applying protocol 3 the fresh pulped material was the starting material providing higher yields, and a better SDS-PAGE band resolution. The use of such material has been extensively reported in literature for leaves and soft green plant tissues (e.g., Pirie 1942; Bryant and Fowden 1959). According to Angell et al. (2017), terrestrial leaves and green seaweeds blades, being physiologically and biochemically similar, can be treated with similar protein extraction methods (Bals and Dale 2011; Chiesa and Gnansounou 2011). All plant cells consist of outermost walls which are made of a complex assembly of polysaccharides (including large anionic pectins) and other compounds and are difficult to disrupt (Lerouxel et al. 2006). Certainly, the most common plant tissue disruption step is pulverizing materials in a mortar and pestle with liquid nitrogen as this practice minimizes protein degradation (Wang et al. 2008a, 2008b). However, maceration of fresh tissues produces an easily separated, protein-rich liquor (Festenstein 1972), favoring elevated protein yields from terrestrial species with more coriaceous (olive) tissues than those of Caulerpa species (Yateem et al. 2014). Similarities between terrestrial leaves and seaweed blades can also explain the low protein concentrations obtained when using dried milled tissues for all the texted protocols (Bals and Dale 2011; Chiesa and Gnansounou 2011).

As opposite to other marine algae, for which a higher incubation temperature appeared to be beneficial for protein extraction (Slocombe et al. 2013), a higher protein yield was observed for Caulerpa species when extracts were obtained at $4^{\circ} \mathrm{C}$. Denaturation may explain the significant protein yield differences observed between samples incubated at $4^{\circ} \mathrm{C}$ and $30^{\circ} \mathrm{C}$ (Faurobert et al. 2007). Finally, the solvent-to-biomass ratio also influenced protein extraction efficiency, as already observed by Shen et al. (2008). In particular, a 10:1 ratio appeared to be the most suitable, especially in terms of protein quality. Even if a higher solvent volume would mean a lower protein concentration in the solvent (Shen et al. 2008), the best ratio is strictly dependent from the considered algae, presumably in relation to the specific variations in total protein content (Fowden 1954).

In conclusion, the best method to obtain high yield and quality protein extracts for $C$. prolifera and $C$. cylindracea appears to be a modified version of protocol 3 , starting from fresh pulped material with a buffer-to-biomass ratio of 10:1 and an incubation temperature of $4^{\circ} \mathrm{C}$ (Fig. 4), as observed also by Karthikaichamy et al. (2017) with a similar protocol for another species (Microchloropsis gaditana (L.M.Lubien) M.W.Fawley, I.Jameson \& K.P.Fawley). The results appeared to be superior in terms of protein abundance, pattern complexity, and molecular weight range. For $C$. taxifolia, none of the tested protocols produced satisfactory results and further studies will be required.

Supplementary Information The online version contains supplementary material available at https://doi.org/10.1007/s10811-021-02479-z.

Acknowledgements We thank Silvia Michelet for the precious help with phenol extraction.

Funding Open access funding provided by Università degli Studi di Milano - Bicocca within the CRUI-CARE Agreement.

Open Access This article is licensed under a Creative Commons Attribution 4.0 International License, which permits use, sharing, adaptation, distribution and reproduction in any medium or format, as long as you give appropriate credit to the original author(s) and the source, provide a link to the Creative Commons licence, and indicate if changes were made. The images or other third party material in this article are included in the article's Creative Commons licence, unless indicated otherwise in a credit line to the material. If material is not included in the article's Creative Commons licence and your intended use is not permitted by statutory regulation or exceeds the permitted use, you will need to obtain permission directly from the copyright holder. To view a copy of this licence, visit http://creativecommons.org/licenses/by/4.0/.

\section{References}

Angell AR, Paul NA, de Nys R (2017) A comparison of protocols for isolating and concentrating protein from the green seaweed Ulva ohnoi. J Appl Phycol 29:011-1026

Bals B, Dale BE (2011) Economic comparison of multiple techniques for recovering leaf protein in biomass processing. Biotechnol Bioeng 108:530-537

Banerjee T, Kishore N (2008) Insights into the energetics and mechanism underlying the interaction of tetraethylammonium bromide with proteins. J Chem Thermodyn 40:483-491

Barbarino E, Lourenço SO (2005) An evaluation of methods for extraction and quantification of protein from marine macro-and microalgae. J Appl Phycol 17:447-460

Belleza DFC, Liao LM (2007) Taxonomic inventory of the marine green algal genus Caulerpa (Chlorophyta, Bryopsidales) at the University of San Carlos (Cebu) herbarium. Philippine Scientist 44:71-104

Beranova-Giorgianni S (2003) Proteome analysis by two-dimensional gel electrophoresis and mass spectrometry: strengths and limitations. Trends Anal Chem 22:273-281

Bradford MM (1976) A rapid and sensitive method for the quantitation of microgram quantities of protein utilizing the principle of protein-dye binding. Anal Biochem 72:248-254

Bryant M, Fowden L (1959) Protein composition in relation to age of daffodil leaves. Ann Bot 23:65-74

Chandini SK, Ganesan P, Bhaskar N (2008) In vitro antioxidant activities of three selected brown seaweeds of India. Food Chem 107:707713

Chiesa S, Gnansounou E (2011) Protein extraction from biomass in a bioethanol refinery-Possible dietary applications: Use as animal feed and potential extension to human consumption. Bioresour Technol 102:427-436 
Contreras L, Ritter A, Dennett G, Boehmwald F, Guitton N, Pineau C, Moenne A, Potin P, Correa JA (2008) Two-dimensional gel electrophoresis analysis of brown algal protein extracts. J Phycol 44:13151321

Contreras-Porcia L, López-Cristoffanini C (2012) Proteomics in seaweeds: ecological interpretations. In: Magdelin S (ed) Gel electrophoresis-advanced techniques. Riejeka, IntechOpen, pp 2152

Cotas J, Leandro A, Monteiro P, Pacheco D, Figueirinha A, Gonçalves AM, da Silva GJ, Prereira L (2020) Seaweed phenolics: from extraction to applications. Mar Drugs 18:384

Faurobert M, Pelpoir E, Chaïb J (2007) Phenol extraction of proteins for proteomic studies of recalcitrant plant tissues. Plant Prot 335:9-14

Festenstein GN (1972) Water-soluble carbohydrates in extracts from large-scale preparation of leaf protein. J Sci Food Agric 23:1409 1415

Fleurence J, Le Coeur C, Mabeau S, Maurice M, Landrein A (1995) Comparison of different extractive procedures for proteins from the edible seaweeds Ulva rigida and Ulva rotundata. J Appl Phycol 7:577-582

Fowden L (1954) A comparison of the compositions of some algal proteins. Ann Bot 18:257-266

Gao Y, Zhang Y, Zhang D, Dai X, Estelle M, Zhao Y (2015) Auxin binding protein $1(\mathrm{ABP} 1)$ is not required for either auxin signaling or Arabidopsis development. Proc Natl Acad Sci U S A 112:22752280

Gao ZF, Li TT, Xu XL, Liu YY, Luo HQ, Li NB (2016) Green lightemitting polyepinephrine-based fluorescent organic dots and its application in intracellular metal ions sensing. Biosens Bioelectron 83: 134-141

García-Otero N, Barciela-Alonso MC, Bermejo-Barrera P, MoredaPiñeiro A, Jiménez MS, Gómez MT, Castillo JR (2013) Assessment of metals bound to marine plankton proteins and to dissolved proteins in seawater. Anal Chim Acta 804:59-65

Ghiani A, Bruschi M, Citterio S, Bolzacchini E, Ferrero L, Sangiorgi G, Asero R, Perrone MG (2016) Nitration of pollen aeroallergens by nitrate ion in conditions simulating the liquid water phase of atmospheric particles. Sci Total Environ 573:1589-1597

Gromov P, Celis JE, Gromova I, Rank F, Timmermans-Wielenga V, Moreira JM (2008) A single lysis solution for the analysis of tissue samples by different proteomic technologies. Mol Oncol 2:368-379

Guan Z, Naparstek S, Calo D, Eichler J (2012) Protein glycosylation as an adaptive response in Archaea: growth at different salt concentrations leads to alterations in Haloferax volcanii S-layer glycoprotein $\mathrm{N}$ glycosylation. Environ Microbil 14:743-753

Guo JL, Lee VM (2014) Cell-to-cell transmission of pathogenic proteins in neurodegenerative diseases. Nat Med 20:130-138

Gygi SP, Corthals GL, Zhang Y, Rochon Y, Aebersold R (2000) Evaluation of two-dimensional gel electrophoresis-based proteome analysis technology. Proc Natl Acad Sci U S A 97:9390-9395

Harnedy PA, FitzGerald RJ (2013) Extraction of protein from the macroalga Palmaria palmata. LWT-Food Sci Tech 51:375-382

Hellerbrand K, Papadimitriou A, Winter G (2001) Process for stabilizing proteins. US Patent No 6:238,664

Isaacson T, Damasceno CM, Saravanan RS, He Y, Catalá C, Saladié M, Rose JK (2006) Sample extraction techniques for enhanced proteomic analysis of plant tissues. Nat Protoc 1:769-774

Jacobs DI, Rijssen MSV, Heijden RVD, Verpoorte R (2001) Sequential solubilization of proteins precipitated with trichloroacetic acid in acetone from cultured Catharanthus roseus cells yields 52\% more spots after two-dimensional electrophoresis. Proteomics 1:13451350

Jongma DN, Campo D, Dattolo E, D'Esposito D, Duchi A, Grewe P, Huisman J, Verlaque M, Yokes MB, Procaccini G (2013) Identity and origin of a slender Caulerpa taxifolia strain introduced into the Mediterranean Sea. Bot Mar 56:27-39
Joubert Y, Fleurence J (2008) Simultaneous extraction of proteins and DNA by an enzymatic treatment of the cell wall of Palmaria palmata (Rhodophyta). J Appl Phycol 20:55-61

Karthikaichamy A, Deore P, Rai V, Bulach D, Beardall J, Noronha S, Srivastava $S$ (2017) Time for multiple extraction methods in proteomics? A comparison of three protein extraction methods in the Eustigmatophyte alga Microchloropsis gaditana. Omics 21:678683

Knigge T (2015) Proteomics in marine organisms. Proteomics 15:39213924

Kraan S (2012) Algal polysaccharides, novel applications and outlook. In: Chang C (ed) Carbohydrates-comprehensive studies on glycobiology and glycotechnology. IntechOpen, London, pp 489532

Laemmli UK (1970) Cleavage of structural proteins during the assembly of the head of bacteriophage T4. Nature 227:680-685

Lerouxel O, Cavalier DM, Liepman AH, Keegstra K (2006) Biosynthesis of plant cell wall polysaccharides - a complex process. Curr Opin Plant Biol 9:621-630

Lim HT, Teo SS (2015) Comparison of protein extraction protocols for proteomic analysis of red algae, Eucheuma cottonii. Pertanika J Trop Agric Sci 38:279-293

Loomis WD, Lile JD, Sandstrom RP, Burbott AJ (1979) Adsorbent polystyrene as an aid in plant enzyme isolation. Phytochemistry 18: 1049-1054

Matanjun P, Mohamed S, Mustapha NM, Muhammad K, Ming CH (2008) Antioxidant activities and phenolics content of eight species of seaweeds from north Borneo. J Appl Phycol 20:367-373

Mohd Rosni S, Fisal A, Azwan A, Chye FY, Matanjun P (2015) Crude proteins, total soluble proteins, total phenolic contents and SDSPAGE profile of fifteen varieties of seaweed from Semporna, Sabah, Malaysia. Int Food Res J 22:1483-1493

Montefalcone M, Morri C, Parravicini V, Bianchi CN (2015) A tale of two invaders: divergent spreading kinetics of the alien green algae Caulerpa taxifolia and Caulerpa cylindracea. Biol Invasions 17: 2717-2728

Olsen JL, Valero M, Meusnier I, Boele-Bos S, Stam WT (1998) Mediterranean Caulerpa taxifolia and C. mexicana (Chlorophyta) are not conspecific. J Phycol 34:850-856

Ortegón-Aznar I, Rosado-Espinosa LA, Aguilar-Perera A (2015) Occurrence of the introduced alga Caulerpa ollivieri Dostál, 1929 (Caulerpaceae, Chlorophyta) in the Southern Gulf of Mexico. Bioinvas Rec 4:17-21

Park SH, Bean SR (2003) Investigation and optimization of the factors influencing sorghum protein extraction. J Agric Food Chem 51: 7050-7054

Peach MJ, Teale AM, Helgaker T, Tozer DJ (2015) Fractional electron loss in approximate DFT and Hartree-Fock theory. J Chem Theory Comput 11:5262-5268

Piazzi L, Balata D, Bulleri F, Gennaro P, Ceccherelli G (2016) The invasion of Caulerpa cylindracea in the Mediterranean: the known, the unknown and the knowable. Mar Biol 163(7):1-14

Pirie NW (1942) Green leaves as a source of proteins and other nutrients. Nature 149:251-251

Rajalingam D, Loftis C, Xu JJ, Kumar TKS (2009) Trichloroacetic acidinduced protein precipitation involves the reversible association of a stable partially structured intermediate. Protein Sci 18:980-993

Ratana-arporn P, Chirapart A (2006) Nutritional evaluation of tropical green seaweeds Caulerpa lentillifera and Ulva reticulata. Agric Nat Resour 40:75-83

Rice EL, Crowden RK (1987) An improved method for the extraction and electrophoresis of proteins and active enzymes from fucalean macroalgae (Phaeophyta). Phycologia 26:235-246

Safdar MN, Kausar T, Jabbar S, Mumtaz A, Ahad K, Saddozai AA (2017) Extraction and quantification of polyphenols from kinnow 
(Citrus reticulata $\mathrm{L}$.) peel using ultrasound and maceration techniques. J Food Drug Anal 25:488-500

Shen L, Weber CR, Turner JR (2008) The tight junction protein complex undergoes rapid and continuous molecular remodeling at steady state. J Cell Biol 181:683-695

Silva PC (2003) Historical overview of the genus Caulerpa. Cryptogam Algol 24:33-50

Slattery M, Ankisetty S, Corrales J, Marsh-Hunkin KE, Gochfeld DJ, Willett KL, Rimoldi JM (2012) Marine proteomics: a critical assessment of an emerging technology. J Nat Prod 75:1833-1877

Slocombe SP, Ross M, Thomas N, McNeill S, Stanley MS (2013) A rapid and general method for measurement of protein in micro-algal biomass. Bioresour Technol 129:51-57

Ukabi S, Dubinsky Z, Steinberger Y, Israel A (2012) Surveying Caulerpa (Chlorophyta) species along the shores of the eastern Mediterranean. Mediterr Mar Sci 13:5-11

Underwood GJC (1997) Microalgal colonization in a saltmarsh restoration scheme. Estuar Coast Shelf Sci 44:471-481

Ünlü M, Morgan ME, Minden JS (1997) Difference gel electrophoresis. A single gel method for detecting changes in protein extracts Electrophoresis 18:2071-2077

Vadlapudi V, Kaladhar DSVGK (2012) Present scenario of algal-omics: a mini review. Res Rev: J Genom Proteom 1:8-12

Vaquer-Sunyer R, Duarte CM, Jordà G, Ruiz-Halpern S (2012) Temperature dependence of oxygen dynamics and community metabolism in a shallow Mediterranean macroalgal meadow (Caulerpa prolifera). Estuar Coasts 35:1182-1192

Wang W, Scali M, Vignani R, Spadafora A, Sensi E, Mazzuca S, Cresti M (2003) Protein extraction for two-dimensional electrophoresis from olive leaf, a plant tissue containing high levels of interfering compounds. Electrophoresis 24:2369-2375

Wang J, Mou H, Jiang X, Guan H (2006) Characterization of a novel $\beta$ agarase from marine Alteromonas sp. SY37-12 and its degrading products. Appl Microbiol Biotechnol 71:833-839

Wang X, Arai S, Song X, Reichart D, Du K, Pascual G, Tempst P, Rosenfeld MG, Glass CK, Kurokawa R et al (2008a) Induced ncRNAs allosterically modify RNA-binding proteins in cis to inhibit transcription. Nature 454:126-130
Wang J, Zhang X, Chen Y, Sommerfeld M, Hu Q (2008b) Toxicity assessment of manufactured nanomaterials using the unicellular green alga Chlamydomonas reinhardtii. Chemosphere 73:11211128

Wong TS, Zhurina D, Schwaneberg U (2006) The diversity challenge in directed protein evolution. Comb Chem High Throughput Screen 9: 271-288

Wu L, Wu H, Chen L, Xie S, Zang H, Borriss R, Gao X (2014) Bacilysin from Bacillus amyloliquefaciens FZB42 has specific bactericidal activity against harmful algal bloom species. Appl Environ Microbiol 80:7512-7520

Xu D, Esko JD (2014) Demystifying heparan sulfate-protein interactions. Annu Rev Biochem 83:129-157

Xu Y, Chen Y, Zhang P, Jeffrey PD, Shi Y (2008) Structure of a protein phosphatase 2A holoenzyme: insights into B55-mediated Tau dephosphorylation. Mol Cell 31:873-885

Xu H, Song J, Luo H, Zhang Y, Li Q, Zhu Y, Xu J, Li Y, Song C, Wang B, Sun W, Shen G, Zhang X, Qian J, Ji A, Xu Z, Luo X, He L, Li C, Sun C, Yan H, Cui G, Li X, Xe L, Wei J, Liu J, Wang Y, Hayward A, Nelson D, Ning Z, Peters Reuben J, Qi X, Chen S (2016) Analysis of the genome sequence of the medicinal plant Salvia miltiorrhiza. Mol Plant 9:949-952

Yan G, Li L, Tao Y, Liu S, Liu Y, Luo W, Wu Y, Tang M, Dong Z, Cao Y (2006) Identification of novel phosphoproteins in signaling pathways triggered by latent membrane protein 1 using functional proteomics technology. Proteomics 6:1810-1821

Yateem H, Afaneh I, Al-Rimawi F (2014) Optimum conditions for oleuropein extraction from olive leaves. Int J Appl Sci Technol 4: $153-157$

Zhang H, Yu H, Zhang L, Song L (2015) Stratification structure of polysaccharides and proteins in activated sludge with different aeration in membrane bioreactor. Bioresour Technol 192:361-366

Zubia M, Draisma SG, Morrissey KL, Varela-Álvarez E, De Clerck O (2020) Concise review of the genus Caulerpa JV Lamouroux. J Appl Phycol 32:23-39

Publisher's note Springer Nature remains neutral with regard to jurisdictional claims in published maps and institutional affiliations. 